\title{
Determining the healthy lifestyle behaviors and e-health literacy levels in adolescents
}

\author{
Determinando os comportamentos de estilo de vida saudáveis \\ e os níveis de letramento e-Saúde em adolescentes \\ La determinación de los hábitos de vida y el nivel de alfabetización e-Salud en adolescentes
}

How to cite this article:

Eyimaya AO, Özdemir F, Tezel A, Apay SE. Determining the healthy lifestyle behaviors and e-health literacy levels in adolescentes. Rev Esc Enferm USP. 2021;55:e03742. https://doi.org/10.1590/S1980-220X2020021603742

\section{Aslihan Öztürk Eyimaya ${ }^{1}$ \\ Funda Özdemir ${ }^{1}$ \\ Ayfer Tezel ${ }^{1}$ \\ Serap Ejder Apay ${ }^{2}$}

${ }^{1}$ Ankara University, Faculty of Nursing, Department of Nursing, Ankara, Turkey.

${ }^{2}$ Atatürk University, Faculty of Health Sciences, Department of Midwifery, Erzurum, Turkey.

\begin{abstract}
Objective: The aim of this study is to determine the healthy lifestyle behaviors and e-health literacy levels of adolescents. Method: A descriptive research design was used in this study. It was conducted with a total of 390 students in the Faculty of Health Sciences. The data were collected using a personal information form, the Healthy Lifestyle Behaviors Scale II and the e-Health Literacy Scale for Adolescents. For data analysis, descriptive analyses, $t$-test, variance, Kruskal-Wallis, the Mann-Whitney U and Pearson Correlation tests were used. Necessary approvals were obtained to conduct this study. Results: The present study found that the e-Health Literacy Scale mean score of adolescents was 27.51 and their HLBS-II mean score was 129.01. A positive significant relationship was found between the e-health literacy and healthy lifestyle behavior in adolescents. Conclusion: This study emphasizes the importance of e-health literacy in developing nursing procedures designed to increase the healthy lifestyle behaviors of adolescents.
\end{abstract}

DESCRIPTORS

Adolescent; Healthy Lifestyle; Health Literacy; Nursing. 


\section{INTRODUCTION}

Adolescence is the transition period from childhood to adulthood. Individuals experience many physiological and psychosocial changes in adolescence, defined as the years between ages 10 and $19^{(1)}$. It is known that the reasons of serious disease and death during this period can generally be prevented, and this depends on behavioral, environmental, and social factors. Therefore, protective services for adolescents gain importance. It is important for adolescents to acquire healthy lifestyle behaviors for the protection and promotion of their health, and to maintain these behaviors into their adulthood $^{(2)}$. "Lifestyle" is defined as the voluntary, daily living activities that are a regular part of one's daily life, and which can seriously affect one's health ${ }^{(3)}$. A study emphasize that closely monitoring the development of adolescents, and supporting healthy lifestyle behaviors in this age group, are important in ensuring a society that consists of healthy adults $^{(4)}$. A study examine the healthy lifestyle behaviors of senior high school students found that the healthy lifestyle behaviors of these students were not at an adequate level ${ }^{(5)}$.

The World Health Organization defines "health literacy" as the cognitive and social skills needed in order for individuals to receive, understand, and use health-related information to improve their health and maintain their good health status. Inadequate health literacy causes inadequate health knowledge, failure to engage in activities that protect health, and inadequate access to and use of health services ${ }^{(6)}$.e-Health literacy is defined as the ability to seek, find, understand, and evaluate health information from electronic sources, and use the information obtained to solve a health problem ${ }^{(7)}$.

According to data from the Turkish Statistical Institute (TSI) for 2017, the age group with the highest computer and internet usage rates is the $16-24$ age group ${ }^{(8)}$. The adolescents who use the internet frequently are expected to have higher levels of e-health literacy-related perception and attitudes. Adolescents may encounter major problems as a result of their access to wrong, misleading and poor quality information on the internet. Therefore, determining the healthy lifestyle behaviors of adolescents and their e-health literacy levels will serve as a guide in developing and planning education, guidance and counseling programs for adolescents, to help them protect and promote their personal health. A study found that the internet awareness levels of students were quite high, their levels of experience using the internet were high, and they considered the internet to be very important as an information search tool ${ }^{(9)}$.

Nurses have a great role in the development of public health and the correct use of health services. In order to achieve this, determining healthy lifestyle behaviors and e-health literacy levels of health sciences students is an important step in increasing students' awareness and knowledge. The aim of this study is to determine the healthy lifestyle behaviors and e-health literacy levels of adolescents.

Research questions:

What is the level of healthy lifestyle behaviors in adolescents?

What is the level of e-health literacy in adolescents?
Is there a relationship between the e-health literacy levels of adolescents and their healthy lifestyle behaviors?

\section{METHOD}

\section{Design OF STUdy}

This descriptive study was conducted to determine the healthy lifestyle behaviors and e-health literacy levels of first-year students in the Faculty of Health Sciences at a university in Turkey. The Faculty of Health Sciences where the present study was conducted includes a total of six departments (nutrition \& dietetics, child development, midwifery, nursing, health care management, and social services). This study was conducted with first-year students who were enrolled during the fall semester and who were not vocational health high school graduates. The reason only first-year students were included in this study was that these students were not influenced about healthy lifestyle behaviors and e-health literacy.

\section{SAMPLE DEFINITION}

The Faculty had a total of 618 first-year students in all departments in the fall semester of the 2017-2018 academic year. The sample selection was not conducted, and it was planned that all of the first-year students being educated in the relevant faculty were contacted.

\section{Data collection}

During the data collection period, a total of 450 students who were in class and agreed to participate in the study were contacted. However, 29 students were excluded from the study because they did not fill out the form completely, 25 students were excluded because they were not included in the adolescent age group, and 6 students were excluded from the study because they graduated from vocational health high school. The data were collected from a total of 390 students (63.1\%).

The data were collected using a personal information form, the Healthy Lifestyle Behaviors Scale II and the e-Health Literacy Scale for Adolescents.

\section{Personal information FORM}

This form consisted of questions related to the sociodemographic characteristics (age, gender, economic status etc.) of the students.

\section{Healthy Lifestyle Behavior Scale II (HLBS III)}

The Healthy Lifestyle Behavior Scale (HLBS) was developed by Walker et al. (1987). The validity and reliability study of the HLBS II in Turkey was conducted by Bahar et al. ${ }^{(10)}$. The result of the validity and reliability study conducted for the Turkish version of the scale showed that the Cronbach's alpha coefficient was 0.92 for the entire scale $^{(10)}$. This study found the Cronbach's alpha coefficient of the scale as 0.90 . HLBS II consists of 52 items and uses a 4-point Likert type scale including the answers, "never", "sometimes", "often" and "routinely". The HLBS II includes 
six subscales: health responsibility, physical activity, nutrition, spiritual development, interpersonal relations and stress management. The lowest possible score is 52, while the highest possible score is 208. As the total score increases, the level of healthy lifestyle behaviors increases ${ }^{(10)}$.

\section{E-HEALTH LITERACY SCALE FOR ADOLESCENTS}

The scale was developed by Norman and Skinner in 2006 to determine traditional literacy, health literacy, information literacy, scientific literacy, media literacy, and computer literacy. The validity and reliability study of the scale for Turkish society was conducted by Coşkun and Bebiş in 2015. The scale consists of 2 items related to internet use and 8 items assessing the attitude towards using the internet. Each item uses a 5-point Likert scale to answer each question with response options including "strongly disagree", "disagree", "neither agree nor disagree", "agree", and "strongly disagree". The lowest total possible score is 8 , while the highest total possible score is 40 . The high scores obtained from the scale indicate the high levels of e-health literacy. The Cronbach's alpha coefficient of the scale is $0.78^{(11)}$. This study determined that the Cronbach's alpha coefficient of the scale was 0.81 .

\section{Data ANAlysis}

The data were analyzed using the SPSS 18 package program. The parametric tests ( $t$-test, variance) for the normally distributed data, and the non-parametric tests (Kruskal-Wallis test, Mann-Whitney U test) and correlative tests (pearson correlation) for non-normally distributed data were used for the analysis, as well as for the descriptive analysis (number, percentage, mean).

\section{ETHICAL ASPECTS}

An ethics committee approval was obtained (date: 11/20/2017, decision numbered: 307 ) and an institutional approval was obtained from the faculty where the study was conducted. Approvals were obtained from the researchers who developed the scales. Before the data collection forms were collected, students included in the study were informed about the aim of this study, and their written consents were obtained.

\section{RESULTS}

The distribution of the descriptive characteristics of adolescents is given in Table 1.

Table 1 - Distribution of adolescents' descriptive characteristics - Ankara, Turkey, 2018.

\begin{tabular}{lcc}
\hline Descriptive Characteristics & Number & Percentage \\
\hline Gender & 329 & 84.4 \\
Female & 61 & 15.6 \\
Male & & \\
Economic status & 93 & 23.8 \\
Income less than expense & 246 & 63.1 \\
Income equivalent to expense & 51 & 13.1 \\
Income more than expense & & continue
\end{tabular}

\begin{tabular}{|c|c|c|}
\hline Descriptive Characteristics & Number & Percentage \\
\hline \multicolumn{3}{|l|}{ Social security } \\
\hline Yes & 327 & 83.8 \\
\hline No & 63 & 16.2 \\
\hline \multicolumn{3}{|c|}{ Place where the participants have spent the majority of their lives } \\
\hline City & 238 & 61.0 \\
\hline District & 110 & 28.2 \\
\hline Village & 42 & 10.8 \\
\hline \multicolumn{3}{|l|}{ Mother's educational level } \\
\hline Illiterate & 26 & 6.7 \\
\hline Literate & 22 & 5.6 \\
\hline Primary school & 170 & 43.6 \\
\hline Secondary school & 69 & 17.7 \\
\hline High school & 64 & 16.4 \\
\hline University & 39 & 10.0 \\
\hline \multicolumn{3}{|l|}{ Father's educational level } \\
\hline Illiterate & 5 & 1.3 \\
\hline Literate & 16 & 4.1 \\
\hline Primary school & 112 & 28.7 \\
\hline Secondary school & 68 & 17.4 \\
\hline High school & 104 & 26.7 \\
\hline University & 85 & 21.8 \\
\hline \multicolumn{3}{|l|}{ Family Type } \\
\hline Nuclear & 336 & 86.2 \\
\hline Extended & 54 & 13.8 \\
\hline
\end{tabular}

Note: $(\mathrm{n}=390)$

Of the students, $54.1 \%$ were 18 years old and $45.9 \%$ were 19 years old. While answering the question included in the e-Health Literacy Scale for adolescents, "How do you think the internet is useful for helping you decide about your health?", $2.8 \%$ of the participants gave the answer, "not useful at all"; $14.6 \%$ gave the answer, "not useful"; $34.6 \%$ gave the answer, "neutral", $44.9 \%$ gave the answer, "useful" and $3.1 \%$ gave the answer, "very useful". Of the participants, $1.3 \%, 12.3 \%$, $22.6 \%, 52.1 \%$ and $11.7 \%$ gave the answers, "not important at all", "not important", "neutral", "important" and "very important", respectively for the question, "How important is the access to health-related sources on the internet for you?".

Distribution of e-health literacy scale and HLBS II scores of adolescents is given in Table 2 .

Table 2 - Distribution of e-health literacy scale and HLBS II mean scores of adolescents - Ankara, Turkey, 2018.

\begin{tabular}{lccc}
\hline Scales & $\mathbf{X} \pm \mathrm{SD}$ & $\begin{array}{c}\text { Possible } \\
\text { Lower } \\
\text { Values-Upper } \\
\text { Values }\end{array}$ & $\begin{array}{c}\text { Marked } \\
\text { Lower } \\
\text { Values-Upper } \\
\text { Values }\end{array}$ \\
\hline $\begin{array}{l}\text { e-Health Literacy Scale } \\
\text { for Adolescents: }\end{array}$ & $27.51 \pm 4.69$ & $8-40$ & $8-40$ \\
HLBS II & $129.01 \pm 17.42$ & $52-208$ & $66-200$ \\
$\quad$ Health responsibility & $20.15 \pm 4.33$ & $9-36$ & $9-36$ \\
$\quad$ Physical activity & $17.22 \pm 4.60$ & $8-32$ & $8-32$ \\
$\quad$ Nutrition & $19.63 \pm 3.57$ & $9-36$ & $10-32$ \\
$\quad$ Spiritual development & $26.67 \pm 4.19$ & $9-36$ & $11-36$ \\
$\quad \begin{array}{l}\text { Interpersonal support } \\
\text { Stress management }\end{array}$ & $26.10 \pm 4.28$ & $9-36$ & $13-36$ \\
\hline Note: $(\mathrm{n}=390)$ & $19.23 \pm 3.56$ & $8-32$ & $10-32$ \\
\hline
\end{tabular}


Table 3 - The comparison of e-health literacy and HBLS-II mean scores in adolescents by their descriptive characteristics - Ankara, Turkey, 2018.

\begin{tabular}{|c|c|c|c|c|c|}
\hline Descriptive Characteristics & Number & $\begin{array}{l}\text { e-Health Literacy Scale for Adolescents } \\
\qquad X \pm S D\end{array}$ & Test and p-value & $\begin{array}{l}\text { HLBS-II } \\
X \pm S D\end{array}$ & Test and p-value \\
\hline \multicolumn{6}{|l|}{ Gender } \\
\hline Female & 329 & $27.37 \pm 4.61$ & \multirow{2}{*}{$t=-1.44 p=0.15$} & $129.24 \pm 16.75$ & \multirow{2}{*}{$t=0.61 p=0.53$} \\
\hline Male & 61 & $28.31 \pm 5.04$ & & $127.75 \pm 20.81$ & \\
\hline \multicolumn{6}{|l|}{ Economic status } \\
\hline Income less than expense & 93 & $26.61 \pm 4.94$ & \multirow{3}{*}{$F=2.30 p=0.10$} & $125.79 \pm 18.09$ & \multirow{3}{*}{$F=2.09 p=0.12$} \\
\hline Income equivalent to expense & 246 & $27.82 \pm 4.58$ & & $130.00 \pm 17.16$ & \\
\hline Income more than expense & 51 & $27.70 \pm 4.61$ & & $130.11 \pm 17.10$ & \\
\hline \multicolumn{6}{|l|}{ Social security } \\
\hline Yes & 327 & $27.72 \pm 4.72$ & \multirow{2}{*}{$t=1.96 p=0.50$} & $129.44 \pm 17.25$ & \multirow{2}{*}{$t=1.09 p=0.27$} \\
\hline No & 63 & $26.46 \pm 4.42$ & & $126.80 \pm 18.27$ & \\
\hline \multicolumn{6}{|c|}{ Place where the participants have spent the majority of their lives } \\
\hline City & 238 & $26.30 \pm 4.48$ & \multirow{3}{*}{$\begin{array}{l}F=2.42 \\
p=0.09\end{array}$} & $125.07 \pm 17.27$ & \multirow{3}{*}{$F=1.48 p=0.22$} \\
\hline District & 110 & $28.14 \pm 4.50$ & & $128.46 \pm 19.00$ & \\
\hline Village & 42 & $27.44 \pm 4.78$ & & $129.96 \pm 16.64$ & \\
\hline \multicolumn{6}{|l|}{ Mother's educational level } \\
\hline Illiterate & 26 & $25.15 \pm 5.23$ & \multirow{6}{*}{$\begin{array}{l}\mathrm{KW}=16.82 \\
\mathrm{p}=\mathbf{0 . 0 0 5}\end{array}$} & $129.42 \pm 21.58$ & \multirow{6}{*}{$\begin{array}{c}\mathrm{KW}=4.82 \\
\mathrm{p}=0.43\end{array}$} \\
\hline Literate & 22 & $25.59 \pm 4.45$ & & $125.00 \pm 16.40$ & \\
\hline Primary school & 170 & $27.38 \pm 4.47$ & & $127.58 \pm 17.38$ & \\
\hline Secondary school & 69 & $28.91 \pm 4.36$ & & $131.13 \pm 18.69$ & \\
\hline High school & 64 & $27.82 \pm 4.97$ & & $129.81 \pm 14.66$ & \\
\hline University & 39 & $27.76 \pm 4.73$ & & $132.17 \pm 17.04$ & \\
\hline \multicolumn{6}{|l|}{ Father's educational level } \\
\hline Illiterate & 5 & $25.80 \pm 4.71$ & \multirow{6}{*}{$\begin{aligned} K W & =18.25 \\
p & =\mathbf{0 . 0 0 3}\end{aligned}$} & $125.00 \pm 17.42$ & \multirow{6}{*}{$\begin{array}{c}\mathrm{KW}=7.73 \\
\mathrm{p}=0.17\end{array}$} \\
\hline Literate & 16 & $26.75 \pm 4.44$ & & $126.31 \pm 16.12$ & \\
\hline Primary school & 112 & $26.27 \pm 4.65$ & & $126.30 \pm 20.05$ & \\
\hline Secondary school & 68 & $28.29 \pm 4.83$ & & $130.95 \pm 16.83$ & \\
\hline High school & 104 & $28.66 \pm 4.42$ & & $131.02 \pm 15.93$ & \\
\hline University & 85 & $27.37 \pm 4.64$ & & $129.31 \pm 16.02$ & \\
\hline \multicolumn{6}{|l|}{ Family Type } \\
\hline Nuclear & 336 & $27.80 \pm 4.63$ & \multirow{2}{*}{$\begin{aligned} M W-U & =6640.50 \\
p & =\mathbf{0 . 0 0 2}\end{aligned}$} & $128.95 \pm 17.54$ & \multirow{2}{*}{$\begin{aligned} M W-U & =8,615.50 \\
p & =0.55\end{aligned}$} \\
\hline Extended & 54 & $25.70 \pm 4.66$ & & $129.38 \pm 16.81$ & \\
\hline
\end{tabular}

Note: $(n=390)$

A significant difference was found among the e-health literacy mean scores of adolescents according to their mothers' educational levels, fathers' educational levels and their family types (respectively $\mathrm{p}=0.05, \mathrm{p}=0.003$, $\mathrm{p}=0.002$, Table 3 ).

The examination of relationships between the e-Health Literacy Scale for Adolescents and HLBS II ( $\mathrm{r}=.260$, $\mathrm{p}$ $=.000$ ) and its subscale (Health responsibility $\mathrm{r}=.214$, $\mathrm{p}$ $=.000$; Physical activity $\mathrm{r}=.225, \mathrm{p}=.000$; Nutrition $\mathrm{r}=.230$, $\mathrm{p}$ $=.000$; Spiritual development $\mathrm{r}=.152, \mathrm{p}=.003$; Interpersonal support $\mathrm{r}=.136, \mathrm{p}=.007$; Stress management $\mathrm{r}=.149$, $\mathrm{p}$ $=.003)$ mean scores showed that there was a positive significant relationship between the e-health literacy for adolescents and the HLBS II and its subscales.

\section{DISCUSSION}

The adolescents gave the answer "useful" at the highest level and "not useful" at the lowest level while answering the question included in the e-Health Literacy Scale for adolescents, "How do you think the internet is useful in helping you decide about your health?". For the question, "How important is the access to health-related sources on the internet for you?" the adolescents gave the answer, "important" at the highest level and "not important at all" at the lowest level. A study emphasized that the internet plays an important role, particularly for students, in higher education institutions, and use of internet is not limited to academic and leisure purposes, but it is also used for the life-sustaining purposes, including the search for health-related information ${ }^{(12)}$. A study, with the students in a faculty of health sciences found results similar to the results of the present study ${ }^{(13)}$.

In the present study, the e-Health Literacy Scale for adolescents mean score was found to be $27.51 \pm 4$.69. There was no cut-off point for the assessment of the e-health literacy scale. The lowest total possible score is 8 , while the highest total possible score is 40 . The high scores obtained from the scale indicate the high levels of e-health literacy ${ }^{(11)}$. Therefore, according to the result of the present study, the e-health literacy levels of adolescents were discussed on the basis of their mean scores in accordance with the literature. A study conducted with medicine and health sciences students found that the e-Health Literacy Scale total mean score was $28.21^{(14)}$. A study found the mean score of the 
e-health literacy scale for adolescents was $27.4^{(11)}$. Another study on a group similar to the study group of the present study found the mean score of the e-health literacy scale for adolescents was $28.26^{(13)}$.

The present study found that the HLBS II mean score was 129.01 . The lowest possible score is 52 , while the highest possible score is 208 . As the total score increases, the level of healthy lifestyle behaviors increase ${ }^{(10)}$. A study found the HLBS II mean score of first-year nursing, nutrition and dietetics, physiotherapy and rehabilitation students was $135.72^{(15)}$. Another study with 1,001 students from 10 high schools found the HLBS II mean score was $128.01^{(16)}$. A study examine the factors affecting the health protective behaviors of nursing students in a university found the HLBS II total mean score and subscale mean scores to be similar to the findings of the present study ${ }^{(17)}$. A systematic review determine the factors affecting the healthy lifestyle behaviors of high school students reported that the mean scores found in the studies using the HLBS II varied between 126.3 and $129.5^{(18)}$.

Another study examine the health literacy levels of medical school students reported that there was a positive correlation between the high educational level of parents and health literacy ${ }^{(19)}$. A study examine the health literacy levels of military university students and the affecting factors found that there was a significant relationship between the level of health literacy and the educational levels of parents ${ }^{(20)}$. Similar to the finding of the present study, these studies found that the educational levels of parents positively affect the health literacy of children. This result emphasizes that the educational levels of parents who have many roles and functions in the family are important to improve the e-health literacy levels of adolescents.

The present study found that the e-health literacy scale mean scores were significantly higher among adolescents who were living within a nuclear family, compared to those with an extended family structure. A study which aimed to determine the health literacy levels of students in vocational health school and the factors that affect them showed that the individuals living in a family with only three members had the highest health literacy mean score, while those living in a family with seven or more members had the lowest mean score. This result shows that the differences in family structure are important, because they affected the e-health literacy levels of adolescents in the present study.

In the present study, the examination of the relationship between the e-Health Literacy Scale for Adolescents and HLBS II and its subscale mean scores showed that there was a positive significant relationship between e-health literacy for adolescents and the HLBS II. This finding shows that as the e-health literacy level increases, the healthy lifestyle behaviors also increase. A systematic review found a significant relationship between the health literacy of adolescents and their health behaviors ${ }^{(21)}$. Another study with internet users reported that there was a relationship between e-health literacy and exercise and balanced nutrition ${ }^{(22)}$. In their study with nursing students, found that healthy literacy and variables regarding the health-related behaviors are closely related ${ }^{(23)}$.

Nurses with high e-health literacy can have positive healthy lifestyle behaviors, give safer advice to their patients and can be positive role models. It is thought that nurses with high ability to research, understand and evaluate electronic health information have more positive healthy lifestyle behaviors. Developing nurses' e-health literacy with various strategies can be used as an effective way to develop healthy lifestyle behaviors of both themselves and the patients they care for.

\section{CONCLUSION}

The present study found that the e-Health Literacy Scale mean score of adolescents was 27.51 and their HBLS-II mean score was 129.01 . A positive significant relationship was found between the e-health literacy and healthy lifestyle behavior in adolescents. This study emphasizes the importance of e-health literacy in developing nursing procedures designed to increase the healthy lifestyle behaviors of adolescents. It is important for adolescents, who are the adults of the future, to acquire and maintain healthy lifestyle behaviors during their entire lifetime. In this respect, nursing interventions should be designed to increase both e-health literacy levels and healthy lifestyle behaviors of adolescents. Determining the healthy lifestyle behaviors of adolescents and their e-health literacy levels will contribute to the development of education, guidance and counseling programs designed to help them protect and promote their health.

\section{RESUMO}

Objetivo: O objetivo deste estudo é determinar os comportamentos de estilo de vida saudáveis e os níveis de letramento e-Saúde de adolescentes. Método: Um desenho de pesquisa descritivo foi utilizado neste estudo. Foi realizado com um total de 390 alunos da Faculdade de Ciências da Saúde. Os dados foram coletados por meio de um formulário de informações pessoais, a Healthy Lifestyle Behaviors Scale II e a e-Health Literacy Scale for Adolescents. Para a análise dos dados, foram utilizadas análises descritivas, teste t, variância, Kruskal-Wallis, Mann-Whitney U e testes de correlação de Pearson. As aprovações necessárias foram obtidas para conduzir este estudo. Resultados: O presente estudo constatou que o escore médio dos adolescentes da e-Health Literacy Scale foi de 27,51 e o escore médio da HLBS-II foram de 129,01. Uma relação positiva significativa foi encontrada entre o letramento e-Saúde e o comportamento de estilo de vida saudável em adolescentes. Conclusão: Este estudo enfatiza a importância do letramento em e-Saúde no desenvolvimento de procedimentos de enfermagem que visam aumentar os comportamentos de estilo de vida saudáveis dos adolescentes.

Adolescente; Estilo de Vida Saudável; Letramento em Saúde; Enfermagem. 


\section{RESUMEN}

Objetivo: El objetivo de este estudio es determinar los hábitos de vida saludables y los niveles de alfabetización e-Salud en los adolescentes. Método: En este estudio se utilizó un diseño de investigación descriptivo. Se realizó con un total de 390 estudiantes de la Facultad de Ciencias de la Salud. Los datos se recopilaron mediante un formulario de información personal, la Healthy Lifestyle Behaviors Scale II y la e-Health Literacy Scale for Adolescents. Para el análisis de datos se utilizaron análisis descriptivos, t-test, varianza, Kruskal-Wallis, la U de Mann-Whitney y las pruebas de Correlación de Pearson. Se obtuvieron las aprobaciones necesarias para realizar este estudio. Resultados: El presente estudio encontró que la puntuación media de la e-Health Literacy Scale de los adolescentes fue de 27,51 y la puntuación media de la HLBS-II fue de 129,01. Se encontró una relación positiva significativa entre la alfabetización en e-Salud y el comportamiento de estilo de vida saludable en los adolescentes. Conclusión: Este estudio enfatiza la importancia de la alfabetización en e-Salud en el desarrollo de procedimientos de enfermería diseñados para aumentar los comportamientos de estilo de vida saludable de los adolescentes.

\section{DESCRIPTORES}

Adolescente; Estilo de Vida Saludable; Alfabetización en Salud; Enfermería.

\section{REFERENCES}

1. World Health Organization. Recognizing adolescence [Internet]. Geneva: World Health Organization. [cited 2017 Dec 30]. Available from: http://apps.who.int/adolescent/second-decade/section2/page1/recognizing-adolescence.html

2. Yiğitalp G. The role of nurses in preventive health services for adolescents. In: Haspolat YH, Aktar F, editors. Adolescent health and diseases. istanbul: Cinius Publications; 2016. p. 87.

3. Pender N, Murdaugh C, Parsons MA. Health promotion in nursing practice. 7h ed. Upper Saddle River: Pearson Education; 2015. Chapter 4, Assessing health and health behaviors; p. 93.

4. McGovern CM, Militello LK, Arcoleo KJ, Melnyk BM. Factors associated with healthy lifestyle behaviors among adolescents. J Pediatr Health Care. 2018;32(5):473-80. https://doi.org/10.1016/j.pedhc.2018.04.002

5. Aktaş Özakgül A, Atabek Aşti T, Ataç M, Mercan K. Do senior high school students have health-promoting lifestyles? [Internet]. Florence Nightingale J Nurs. 2016 [cited 2017 Dec 4];24(1):16-23. Available from: https://fnjn.org/en/do-senior-high-school-students-have-health -promoting-lifestyles-13428

6. World Health Organization. Health promotion [Internet]. Geneva: World Health Organization [cited 2017 Oct 19]. Available from: http:// www.who.int/healthpromotion/about/HPR\%20Glossary\%201998

7. Norman CD, Skinner HA. E-health literacy: essential skills for consumer health in a networked world. J Med Internet Res. 2006;8(2):e9. https://doi.org/10.2196/jmir.8.2.e9

8. Türkiye İstatistik Kurumu. Hanehalkı Bilişim Teknolojileri Kullanım Araştırması [Internet] 2017 [cited 2017 Dec 30]. Available from: https:// data.tuik.gov.tr/Bulten/Index?p=Hanehalki-Bilisim-Teknolojileri-(BT)-Kullanim-Arastirmasi-2017-24862

9. Aytaç T, Erdem M. Examining high school students'safe computer and internet usage awareness. Eur J Educ Stud. 2019;6(1):295-311. https:// doi.org/10.5281/zenodo.2652846

10. Bahar Z, Beşer A, Gördes N, Ersin F, Kıssal A. [Healthy life style behavior scale II: A reliability and validity study] [Internet]. C.Ü. Hemşirelik Yüksekokulu Dergisi. 2008 [cited 2017 Dec 8];12(1):1-13. Turkish. Available from: https://toad.halileksi.net/sites/default/files/pdf/saglikliyasam-bicimi-davranislari-olcegi-ii-toad.pdf

11. Coşkun S, Bebiş H. [Psychometric evaluation of a Turkish version of the e-health literacy scale (e-heals) in adolescente]. Gülhane Tıp Derg. 2015;57(4):378-84. Turkish. https://doi.org/10.5455/gulhane.157832

12. Osei Asibey B, Agyemang S, Boakye Dankwah A. The internet use for health information seeking among Ghanaian University students: a cross-sectional study. Int J Telemed Appl. 2017;2017:1756473. https://doi.org/10.1155/2017/1756473

13. Şengün H, Çınar F, Çapar H, Bulut A, Çakmak C. [E-health literacy levels of health sciences faculty students and attitudes for using internet: a foundation university sample]. [Internet]. J Soc Humanit Sci Res. 2017 [cited 2017 Nov 6];4(5):1277-87. Turkish. Available from: http:// www.jshsr.org/Makaleler/776249242_62_ID.187_2017_JSHSR_4-5.\%c5\%9eeng\%c3\%bcl,\%c3\%87\%c4\%b1 nar,\%c3\%87apar,Bulut,\%c $3 \% 87$ akmak_1277-1287.pdf

14. Dashti S, Peyman N, Tajfard M, Esmaeeli H. E-Health literacy of medical and health sciences university students in Mashhad, Iran in 2016: a pilot study. Electron Physician. 2017;9(3):3966-73. https://doi.org/10.19082/3966

15. Köseoğlu Örnek Ö, Kürklü A. [Healthy lifestyle behaviours, levels of self efficacy among university students and affected factors]. Turkiye Klinikleri J Nurs. 2017;9(3):207-17. Turkish. https://doi.org/10.5336/nurses.2016-54198

16. Dil S, Gönen Şentürk S, Aykanat Girgin B. [Relationship between risky health behaviors and some demographic characteristics of adolescents' self-esteem and healthy lifestyle behaviors in Çankırı]. Anadolu Psikiyatri Derg. 2015;16(1):51-9. Turkish. https://doi. org/10.5455/apd.48433

17. Polat Ü, Özen Ş, Kahraman BB, Bostanoğlu H. Factors affecting health-promoting behaviors in nursing students at a university in Turkey. J Transcult Nurs. 2016;27(4):413-9. https://doi.org/10.1177/1043659615569536

18. Sümen A, Öncel S. [Factors that affect healthy lifestyle behaviors of high school students in Turkey: a systematic review]. Eur J Ther. 2017;23(2):74-82. Turkish. https://doi.org/10.5152/EurJTher.2017.04044

19. Zhang Y, Zhang F, Hu P, Huang W, Lu L, Bai R, et al. Exploring health literacy in medical university students of Chongqing, China: a cross-sectional study. PLoS One. 2016;11(4):e0152547. https://doi.org/10.1371/journal.pone.0152547

20. Rong H, Cheng X, Garcia JM, Zhang L, Lu L, Fang J, et al. Survey of health literacy level and related influencing factors in military college students in Chongqing, China: a cross-sectional analysis. PLoS One. 2017;12(5):e0177776. https://doi.org/10.1371/journal.pone.0177776 
21. Fleary SA, Joseph $P$, Pappagianopoulos JE. Adolescent health literacy and health behaviors: a systematic review. J Adolesc. 2018;62(62):116-27. https://doi.org/10.1016/j.adolescence.2017.11.010

22. Mitsutake S, Shibata A, Ishii K, Oka K. Associations of ehealth literacy with health behavior among adult internet users. J Med Internet Res. 2016;18(7):e192. https://doi.org/10.2196/jmir.5413

23. Kolnik TŠ, Hozjan D, Babnik K. Health literacy and health related lifestyle among nursing students. Pielegniarstwo XXI wieku. 2017;16(2):42-6. https://doi.org/10.1515/pielxxiw-2017-0017

\begin{tabular}{|l|l}
\hline (cc) BY This is an open-access article distributed under the terms of the Creative Commons Attribution License. \\
\hline
\end{tabular} 